\title{
The Uninvited Skeleton at the Archaeological Table: The Crisis of Paleoanthropology in South Asia in the Twenty-first Century
}

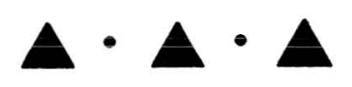

KENNETH A. R. KENNEDY

The Greek Biographer Plutarch (A.D. 45-120) reported in an essay of his Morales that the Egyptians of his day always placed a human skeleton in a prominent place at their banquets as a reminder that life brings troubles as well as pleasures. Thus was coined the popular phrase "the skeleton at the feast." Although these gloomy guests were countenanced by ancient Egyptian diners, some present-day archaeologists exhibit a less welcoming reaction when encountering human bones, teeth, and the occasional hank of hair resting on their laboratory tables alongside associated artifacts of greater appeal. This sentiment was eloquently expressed by the late Sasanka S. Sarkar (1908-1969), a biological anthropologist at the University of Calcutta:

I have felt that archaeologists of this country are not yet so interested in skeletal remains as they are with potsherds. I tried to ascertain in certain cases as to what happened with the excavated skeletal remains, their whereabouts, or the completion of their reports, but I failed to obtain a scientific answer from any quarter. And if those facts were available, some lacunae in our knowledge would have been filled up.... The reconstruction of the skeletal remains should not be considered at par with pottery-washing and mending. (Sarkar 1972:x)

In short, the osteological company is not always welcome at the archaeological banquet, and South Asia has not escaped the consequences of this attitude held over the past two centuries by Orientalists, antiquarians, and archaeologists. Some excavators have left the burials unexhumed; others packed them off to a museum or other institution, where they linger unexamined for decades; and not infrequently the excavated skeletons were lost, purposefully destroyed, or reburied without scientific study (Kennedy 2000:37-44). Despite these tragedies, many valuable collections of prehistoric human remains have been preserved, examined by trained biological anthropologists, and results of their investigations published. Prospects for a closer affiliation of archaeologists with their biological anthropology colleagues, specializing in the subdiscipline of paleoanthropology, are encour-

Kenneth A. R. Kennedy is Professor of Ecology and Evolutionary Biology, Anthropology, and Asian Studies, Cornell University, Ithaca, New York.

Asian Perspetie's, Vol. +2, No. 2 ( 20$) 3$ by the University of Hawaiti Press. 
aging, and this trend is best demonstrated by a brief summary of the history of developments that have taken place in South Asia during the last century.

\section{TRANSITIONS IN PALEOANTHROPOLOGICAL PERSPECTIVES}

Paleoanthropology is the scientific study of biological diversity and evolution of prehistoric human populations as reconstructed from the discovery and interpretation of fossil remains, archaeological evidence, and ancient ecological settings in different parts of the world. When I entered the field of South Asian paleoanthropology in 1960, the following questions were of primary importance to my Indian and Western colleagues:

1. What is the phylogenetic relationship of the Miocene-Pliocene apes, whose fossils had been recovered from the Siwalik Hills of northern India and western Pakistan, to the earliest members of the human taxonomic family, the Hominidae?

2. Could the manufacturers of prehistoric stone tools found in the Indian subcontinent be linked, both biologically and culturally, to specific living populations that Western and Indian anthropologists had classified into racial categories?

3. Who were the creators of the Indus (Harappan) civilization, and what happened to their culture and populations after 1700 B.C.?

4. What is the skeletal and archaeological evidence of the presence of the first Indo-European-speaking people in South Asia, more specifically the Aryans of the Hindu Vedic tradition?

5. Has South Asia been a biological and cultural cul-de-sac absorbing foreign populations with distinctive cultural traditions imported from lands beyond the Himalaya? Or were some, perhaps all, major cultural developments within the subcontinent achieved independently and not acquired by cultural diffusion and foreign invasions?

The questions posed today by paleoanthropologists active in South Asia bear little resemblance to those listed above and new issues dominate the study of the earlier peoples in this part of the world. What has caused this transition?

\section{MIOCENE-PLIOCENE APES IN SOUTH ASIA}

Some issues faded away or became modified because of substantial additions to the prehistoric skeletal and archaeological records. One significant change in the interpretation of hominid origins and antiquity relates to the dethronement of Ramapithecus as the Siwalik Miocene ape formerly accorded the status of a protohominid. Fossilized gnathic and dental remains of various species of Miocene pongids have been found in the Siwalik region since 1836 (Kennedy and Ciochon 1999), and the first suggestion that some fossil specimens within the collection were representative of a hominid ancestor was advanced a century later (Lewis 1934). This thesis gained popularity after 1965 through the investigations and writings of two paleoanthropologists, E. L. Simons and D. R. Pilbeam (1965). Discoveries of more complete fossils in the 1970 s revealed the close phylogenetic affinities of Ramapithecus to a sivapithecine ape lineage that may have been the progenitor of the living species of Pongo, the orangutan of Borneo and Sumatra (Pilbeam et al. 1977, 1990). This interpretation gained support from the evidence 
of molecular biology that African apes and humans separated from a common ancestor some 5 to 6 million years ago (Sarich and Cronin 1976) and not within the 17- to 9-million-year range that had been assumed by some earlier paleoanthropologists (Keith 1929).

The current estimations of dating hominoid-hominid origins from a common ancestral species are set between 8 and 7 million years ago, as based upon recently recovered fossils of Late Miocene age in Ethiopia. However, the phylogenetic affinities of these specimens with sivapithecine and other Miocene apes of Africa, Asia, and Europe remain uncertain (Begun et al. 1997; Pilbeam 1997).

\section{FOSSIL HOMINID DISCOVERIES IN AFRICA AND ASIA}

However, the conviction held by many paleoanthropologists that the earliest hominids evolved in some "center of origin" in Asia, perhaps in India or Central Asia, from which their descendants diffused to other parts of the world, seemed evident from the paleontological discoveries of Homo erectus (formerly called Pithecanthropus erectus) from Java and China and the fossils collected in the Siwalik Hills (Smith 1930:69). The concept of a hominid center of origin continues today, but following the Second World War a paradigmatic shift occurred in paleoanthropological circles, whereby that locus was shifted from Asia to Africa (Dennell 2001:45).

Several factors led to this change, although Asia continued to contribute to the hominid fossil record from middle to late Pleistocene antiquity with new discoveries at Sangiran in Java in 1937 and at Zhoukoudian (formerly Choukoutien) and other localities in China. The discovery in 1982 of an anatomically archaic Homo sapiens fossil in the Narmada Valley in central India is associated with late middle Pleistocene faunal remains and tools of the Acheulian tradition (Kennedy et al. 1991; Misra et al. 1990; Sonakia 1984). Anatomically modern Homo sapiens skeletons dating to 34,000 years ago in microlitherous cave sites in Sri Lanka provide a record of human evolution in South Asia that is contemporary with the CroMagnon people of Europe (Deraniyagala 1992; Kennedy et al. 1987; Kennedy and Zahorsky 1997). And if the dates for chopper tools collected in the northwestern sector of Pakistan are confirmed, then the earliest settlement of the subcontinent by hominids took place as early as 2.2 million years ago (Dennell 1998).

According to the British archaeologist Robin Dennell (2001), the "Demise of Asia" began with the political transition from colonialism to independence. The hiatus in paleoanthropological research left by departing British and Dutch colonial civil servants and military personnel was replaced by research directorships in the hands of other foreign investigators, among whom Americans were predominant, as well as by the intensive leadership by native scholars in their respective countries.

However, an even more critical agent of change involved the increasing successful endeavors of paleoanthropologists working in Africa, as exemplified by Louis and Mary Leakey's discoveries at Olduvai Gorge (Leakey 1959), and the opening up of East Africa as the new center of hominid evolution. Although the discovery of the earliest australopithecine fossil record in South Africa dates to 1924 (Dart 1925), the failure of the paleoanthropological establishment to accept any fossil primate as homind unless its brain size was within the range of cranial capacities of modern humans meant that the South African fossils were 
relegated to species of extinct apes. By 1953, when the Piltdown fragments were revealed as a hoax (Weiner et al. 1953), it came to be recognized that increase in brain size, as estimated by cranial capacities of fossil skulls, was a later hominid development preceded by evolution of habitual erect posture and bipedal locomotion - the present criterion of hominid status among the primates.

Africa gained the prestige of being the continent containing the most ancient hominids as various chronometric procedures moved the timeframe of their evolution as far back as the late Miocene (Baltar 2001). Given the intensive investment of research funding for increasing numbers of paleoanthropologists selecting Africa as their base of operations, it is not surprising that discoveries of hominid fossils of Pliocene and Pleistocene antiquity have increased along the Rift Valley, South Africa, and Chad. Today these specimens are designated by multiple genus and species taxa, hence construction of phylogenetic trees and cladistic models have become complex and controversial. Certainly no single species of hominid survived alone in Africa until the late Pleistocene.

A classic paper by the molecular biologist R. L. Cann, published in The Sciences in 1987, initiated a flood of genetic studies claiming that the center of origin of anatomically modern Homo sapiens was also in Africa, these first members of our direct ancestors dating to c. 200,000 years ago. According to this hypothesis, the descendants of this "Mitochondrial Eve" continued to evolve in Africa while enclaves of that population migrated to Asia and Europe some 100,000 years later, displacing the non-African hominid populations, which were assumed to have been of one or more different species. Although this "Out-of-Africa" model of human evolution does not go unchallenged (Tattersall 1997; Wolpoff 1999), the fact remains that Africa rather than Asia holds center stage among a majority of present-day paleoanthropologists, and journalistic proclamations that the, "newest finds of the most ancient fossil discovered in Africa will necessitate the revision of all textbooks about human evolution" (Tattersall 1997) dominate the popular news media.

The apparent absence of fossils of any early hominids from India and Central Asia has excluded that continent in the "fossil-led" impetus for further work in Africa, which has yielded the remains of the late Miocene Orrorin, Pliocene Ardipithecus and Kenyapithecus, and Pliocene-early Pleistocene Australopithecus, Homo habilis, and Homo rudolfensis. These significant fossil discoveries have caused Asia to be perceived through African eyes, with the result that Asia has been deemed paleoanthropologically peripheral. However, the notion of a specific geographical center identifiable as the locus of hominid origins has its roots in an earlier anthropological view of human evolution, for the anatomically modern Homo sapiens skeletons have been recovered at sites across vast reaches of that continent, from the Capetown region of South Africa northeastward to Israel.

The paucity of lower and middle Pleistocene fossil hominids from South Asia, with the exception of the Narmada calvaria, has been attributed by Michael D. Petraglia

to taphonomic processes in fluvial contexts, biasing the recovery of fauna $>6() \mathrm{kg}$ in weight (Dennell 1998). For this reason, more success in finding hominid fossils may come from much needed and intensive survey in low energy settings (e.g., travertines, paludal deposits) where small mammalian fauna may be identified (Petraglia 1998). Given the current lack of human paleontological finds in India, studies of hominids must come from archaeological research. (2001:219) 
Thus far in the history of South Asian paleoanthropology, the hominid skeletal record is not well represented until late Pleistocene times.

\section{LINKS BETWEEN ARCHAEOLOGY AND HUMAN BIOLOGICAL VARIABILITY}

Another transition in paleoanthropological perspective relates to attempts to racially identify the manufacturers of Paleolithic and Mesolithic stone tools, the Bronze Age founders of the Indus civilization of the third millennium B.C., and the Iron Age megalith-builders. Biological affinities were sought between ancient and contemporary populations as well as with populations beyond the borders of the Indian subcontinent. Colonial domination was not the only source of a preoccupation with racial typologies, although the Census of India report of 1931 has been held responsible for establishing the model of how the native populations of British India should be classified (Guha 1935; Risley 1908). The majority of Indian biological anthropologists of the pre-Second World War period received their advanced training in Germany: L. K. Anathakrishna Iyer, P. C. Biswas, K. Bhasin, S.R.K. Chopra, R. Anathakrishnan, S. S. Sarkar, P. C. Dutta, I. Karve, A. K. Mitra, I. P. Singh, V. P. Chopra, A. R. Banerjee. German anthropologists had been intensively involved in South Asian biological anthropology: E. von Eickstedt, E. Schmidt, E. Büchi, S. Ehrhardt, W. Bernhard, H. Walter, I. Schwidetsky (Schwidetzky 1983). Not only were certain German universities highly regarded centers for anthropological research and training during the first third of the twentieth century, but Germany had no colonial aspirations in South Asia. Furthermore, German anthropologists knew English so that communication with native South Asians was not inhibited. The only well-known Indian biological anthropologist trained in the United States was B. S. Guha, later DirectorGeneral of the Anthropological Survey of India in Calcutta.

Following the end of the Second World War in 1945, the partition of India and Pakistan two years later, and Sri Lankan independence in 1948, Western anthropologists abandoned the traditional concepts of racial typology that had characterized the earlier history of their discipline. Systematic biologists established that subspecific classifications could not define natural entities since all varieties within a given species formed open genetic systems (Kennedy 1976; Montagu 1964; Wilson and Brown 1953). The trinomial designation is retained only for the sake of convenience in identification of specific populations, and their geographical localities and ecological settings gained importance in understanding species biological diversity as adaptive mechanisms in space and time. The UNESCO Statements on Race (1950; Montagu 1942, 1951) reinforced the end of racial typology and racial paleontology, especially in the United States where Franz Boas (1940) had trained a generation of anthropologists that "race, language, and culture" were nonconcordant phenomena.

No survey of earlier issues of primary importance to paleoanthropologists in South Asia can exclude the myth of the Aryan invasion of a nomadic people from a mysterious homeland into the northern sectors of the Indian subcontinent c. 1500 B.C. With this demic event, Indo-European languages and a Vedic cultural tradition were introduced to the Indian aboriginal populations speaking languages of different linguistic stocks. Beginning with the writings of the British comparative linguist William Jones (1746-1794) (1786), the Orientalists created a sce- 
nario of how Indo-European languages diffused across India, the Middle East, and Europe from an unknown center. Their interpretations were based upon textual sources that became amalgamated with Indian religiously sanctioned accounts of the origin and social structure of the caste system. The interaction of ideas between Western and South Asian scholars over interpretations of this Vedic material, often considered to record actual historic events following the decline of the Indus civilization, if not directly related to that decline, constitutes a unique aspect of South Asian paleoanthropology. Western prehistorians and biological anthropologists do not encounter this circumstance in the contexts of their investigations in other parts of Asia, Africa, or Europe (Kennedy 2000:67-85, 365-376).

\section{PRESENT-DAY ISSUES}

Today certain topics of major importance to paleoanthropologists active in South Asia are strikingly different from those of only four decades ago. Current questions meriting investigation include:

1. What is the archaeological and/or paleontological evidence of earliest hominid settlement in South Asia? Did first settlement occur in the Pliocene?

2. Do South Asian prehistoric human remains reveal biological affinities with living populations within the subcontinent and beyond its borders?

3. How have socioeconomic and technological changes in prehistory affected human body form and size, muscular-skeletal robusticity, sexual dimorphism, ontogenetic growth and development, changes in dental anatomy and molar tooth size, and osseous-dental changes related to pathological and traumatic agents? These foci of research provide demographic profiles of extinct populations represented by a skeletal record that cannot be fully reconstructed from the archaeology of a site, such as determination of the sex and age of individuals within a cemetery, frequencies of pathological and traumatic stresses leaving diagnostic markers on bones and teeth, markers of occupational (or habitual activity) stress that lead to particular forms of bone remodeling, and patterns of individual and communal responses to stressors demanding a broad spectrum of adaptive responses.

4. How can the pseudo-historical tradition of an Aryan invasion of India and the association of an assumed Aryan presence, long associated with the social institution of the caste system and the racial classifications of earlier generations of anthropologists, be reinterpreted through scientific investigations based upon field and laboratory research?

5. Which cultural elements of ancient South Asian peoples were acquired by diffusion from lands beyond the Himalaya (a circumstances that need not assume migrations of foreign peoples into the subcontinent, but not limiting consideration of this possibility with respect to specific technological and conceptual elements), and which cultural elements were of indigenous origin?

6. Which biological developments were adaptive for survival in the shift from hunting-foraging to food-production by farming and hording practices which involved sedentary village life, nomadism, and increases of population density?

7. Where does South Asian paleoanthropology fit into the broader worldwide area of prehistory, particularly with respect to Indo-European languages and the 
concepts that have emerged in determining the places of origin and pathways of the diffusions of these tongues? Related to this issue is the question of tracing the pattern of population movements both within and without the Indian subcontinent with consequent directions of gene flow.

Racial categories continue in social thought in South Asia where phenotypic diversity is confused with a faith that races are classifiable natural entities. This survival of the traditional concepts of an earlier era of anthropological practice continue to characterize palaeoanthropology, as observed in the writings of some contemporary South Asian scholars. One example of this adherence to an outdated model of human biological diversity is the map of Guha's racial classification displayed in the Indian National Museum in New Delhi, a variation of the racial scheme designed in the 1920 s by his mentor at Harvard University, Ronald Dixon (1875-1934) (1923).

The origins of the Bronze Age Harappans are now better understood through discoveries of pre-Harappan cultures dating as early as 7000 B.C. in Baluchistan (Jarrige and Lechevallier 1979). Today there are more convincing theories of Harappan decline with the exclusion of the myth that invading Aryan hordes had massacred the citizens of Mohenjo-daro, one of the large urban centers of that civilization (Kennedy 1995; Possehl 1999; Wheeler 1968). Continuing excavations at Harappa since 1986 by a joint Pakistani-American team included four biological anthropologists who have provided detailed descriptions of newly recovered skeletons from cemetery R37 as well as a reassessment of all skeletons recovered from this and other sites of the Harappan realm (Hemphill et al. 1991). Results of multivariable analyses offer new palaeodemographic data not revealed by archaeology alone.

Among other advances are the recognition that the megalith-builders of the South Asian Iron Age were members of heterogeneous populations, not biologically homogeneous or mysterious foreigners missionizing from a Druidical diocese on the Salisbury Plain or immigrants from Iran (Kennedy 1975; Sarkar 1972). The identification and mapping of pathological responses to environmental stressors from the late Pleistocene to the dawn of the Historic period in South Asia (Lovell 1997; Lukacs and Walimbe 1998) parallels other recent studies of how prehistoric populations adapted to changing ecological and cultural stresses.

In short, it would seem that paleoanthropology of South Asia has shifted from a preoccupation with a classificatory model of race identification to an evolutionary paleodemographic paradigm. But has it?

I find that many of my respected South Asian colleagues agree in principle to the fall of the traditional race concept, but the venerable practice of polytypic sorting of ancient and living peoples survives in much of their published materials. Why is this the case? I propose that several factors are relevant to this issue:

1. Older generations of Western and South Asian anthropologists found it expedient, even reasonable, to interweave the Hindu caste system with race classification. We see this in the 1901 Census of India compiled by Herbert Risley (1851-1911) (1908) and perpetuated, with some modifications, by B. S. Guha (1935).

2. The origin of the caste system is traced to the Vedic accounts wherein high caste individuals are directly associated with the Aryan Indo-European-speaking "conquerors" to whom classical Hindu religious and social institutions are attrib- 
uted beginning in the mid-second millennium B.C. Since the majority of bettereducated persons in India today are members of the elevated Brahmin caste, the story of population diversity expressed in caste and racial identities has personal relevance.

3. Survival of the race concept exists in efforts to determine the origins of the ancient Harappans, the megalith-builders, and tribal populations outside of the four varnas of the caste system. These anthropological studies do not include inquiries into evolutionary processes, environmental stressors, or paleodemographic configurations. This is not a matter of South Asian scholars rejecting evolutionary theory, genetics, and new scientific approaches to the study of earlier populations so much as it is the issue that their Western colleagues do not seem to address those questions that are still regarded as important in the complex patterns of modern South Asian societies. Even investigators of genetic profiles in rural and urban communities appear to Western readers to be reducible to exercises in racial classification, although many studies provide invaluable genetic data (Bhasin et al. 1994).

4. That some of our South Asian colleagues discern the differences of their own and Western approaches to the reconstruction of their prehistory is illustrated in a statement by the scholar Paramesh Choudhury in his book The Aryans in which he notes that, "The foreign scholars write annals, memoirs, chronicles, but the true song of the land (Bharata/India) can only be sung by someone of her own blood" (1993:6). This pronouncement is puzzling to Western scholars who conceive of the results of scientific research to be of universal and international significance and without cultural borders.

5. Thus Western paleoanthropologists, who may be unfamiliar with these nationalistic attitudes in their quest for sound hypotheses about the origins, antiquity, and evolution of the ancient peoples of South Asia, are often unable to evaluate the interpretations of their Indian colleagues, a problem exacerbated by availability of many non-Western scientific journals and books of which some do not contain data evaluated through the filter of an international peer review process.

\section{PROSPECTS FOR THE TWENTY-FIRST CENTURY}

The persistence of earlier anthropological models and veneration of certain ancient texts as accurate historical sources by both Western and South Asian authors have consequences that characterize the status of paleoanthropology in this part of the world in the new millennium.

This discipline is practiced in the subcontinent by both South Asian and foreign scholars, but the research institutions of the latter group control greater financial resources that allow for extensive and continuing work within specific localities, e.g., the French teams at Mehrgarh (Jarrige and Lechevallier 1979), the American teams at Harappa (Meadow 1991) and Rojdi (Possehl and Raval 1989), and the Italians in the Swat Valley (Stacul 1987). During the Raj, the British were active in many parts of India and Sri Lanka, and today there is a British Archaeological Mission in Pakistan (Allchin 1995). While foreign programs are welcome and tolerated, full leadership is not always in the hands of the citizens of South Asia, although explorations and excavations are conducted in close collaboration 
with officers of governmental archaeological surveys and with faculties of certain universities. The stigma of colonization lingers, although collaboration with foreign scholars is the rule. Indeed, in my many years of work in India, Pakistan, and Sri Lanka, I have encountered only friendship, cooperation, collaboration, and courtesy. However, I can appreciate the sentiment that scholars of South Asian nations should be the key interpreters of their prehistoric forebears (Mathur 2000). This is a controversial issue in other independent nations, with or without colonial histories, in which present-day paleoanthropological research is forged by foreign scholars and their supporting institutions, e.g., in East African nations (Kalb 2000; White 2001; Willis 1989), in China and Southeast Asia (Pope 1994, 1997), in Australasia (Corbey and Roebroeks 2001), in European countries (Sklenaf 1983), in the biblical lands of the Near East (Metzger and Coogan 1993), and in North and South America (Bioisi and Zimmerman 1997; Dewar 2002; Spencer 1997; Thomas 2000). The literal interpretation of textual sources and an archaeological record is not a circumstance unique to South Asia.

Without solid financial support for paleoanthropological research, allocated by governmental and educational institutions in these nations, the anthropology graduate student does not find the scientific study of the ancient dead to be a fruitful field for investigation or career commitment. At the present time there are no well-established paleoanthropologists in Nepal, Bangladesh, Sri Lanka, Afghanistan, or Burma. India should be proud of her acceptable number of paleoanthropologists in the past, but with retirements and deaths of those scholars trained abroad before the Second World War, many administrative and teaching positions remain unfilled. Consequently, those graduates with training in biological anthropology in India, of which there are many, are encouraged to enter research areas with apparent "applied" aspects. Governments are more inclined to support research providing data on medical and genetic issues, health care, and demography. Archaeology students have greater opportunities for career choices, particularly in projects involving restoration of historic monuments and in conservation. One of my colleagues in India, Ravi Korisettar, informed me that in 2001 there were only two or three research centers in his country where sophisticated studies of prehistoric human skeletal remains could be conducted today, and that in many cases the program of a given archaeological excavation does not include recovery and safe delivery of the burial remains to laboratories. This crisis is compounded when one considers the absence of an agenda for these experts to train successors and establish apprenticeships with younger colleagues who will replace them at time of retirement.

At the dawn of the present millennium, very few young scholars are being trained in paleoanthropology. There are officers of junior and senior grades at the Anthropological Survey of India in Calcutta who curate the bulk of the prehistoric skeletal collections, and at Deccan College in Pune. S. R. Walimbe (Walimbe and Kulkami 1993; Walimbe and Taveras 1992) has published results of his valuable research in skeletal biology and dental anthropology of specimens from prehistoric burial sites in India. Odontological studies were advanced in India by the American scholar John R. Lukacs (1984) and by the Indian anthropologist Rami Reddy (1985). DNA analysis of ancient human bone specimens were attempted by S. S. Kumar and his associates (Kumar et al. 2000). 
Present-day South Asian archaeologists and cultural anthropologists are aware that all is not well in their disciplines (Bhattacharya 2000; Mathur 2000), but it is curious that in formulating strategies for educational changes, the value of the scientific analyses of the prehistoric skeletal record is overlooked despite its potential toward reconstruction of ancient cultures and patterns of behavior. The expense of training young aspirants for a profession in paleoanthropology in Europe or North America is often not feasible, and graduate-level fellowships are few. Anthropometry and racial classification remains strongly implanted within the anthropological curricula of many South Asian institutions of higher learning.

However, a more fundamental problem than financial allocations for research must be faced in the new millennium, namely the failure of the passing generation of eminent South Asian scholars to ensure that there is a continuity of their paleoanthropological discipline by training a future generation of researchers among their graduate students and institutional staff members. Personal interviews conducted by the author indicate that among some of the older and retired investigators, for whom there is enforced retirement at the age of 55 years, there is an attitude that once their own research has been accomplished they need not have successors. One element of lack of infrastructure and appointments of welltrained future personnel is a sense of individual ownership of archaeological and osteological specimens recovered during the periods of one's active field research. This problem, while not universal, reflects a disregard for the advancement of the scientific discipline to which a lifetime of work has been devoted. Proper curation of specimens suffers as a consequence of this mindset as storage facilities are not maintained for security and temperature control, and their availability and sound preservation for future investigators is compromised. The best-curated collections are those associated with the activities of foreign scholars in the Pakistan site localities in the Swat Valley, Baluchistan, and Harappa, and with Indian curators at the Anthropological Survey of India in Calcutta and at Deccan College in Pune.

The question remains, what must happen to advance South Asian paleoanthropology into the twenty-first century? A look at what has transpired in earlier historic periods of paleoanthropology offers hope and provides a comparative perspective regarding the challenges facing paleoanthropologists working in different geographical areas. Europe entered this scientific endeavor in the midnineteenth century with the discovery of Neanderthal and anatomically modern Homo sapiens fossils (Stringer and Gamble 1993; Wolpoff and Caspari 1999). Southeast Asia and China became center stage with discoveries of Homo erectus fossils some four decades later (Pope 1994, 1997). Then South Africa and East Africa entered the arena by the middle of the twentieth century and continues, as does Europe and Asia, to produce an amazing hominid fossil record (White 2001).

South Asia can do no less. This vast landmass between Europe, Africa, and eastern Asia was not bypassed by our earlier hominid ancestors, as documented by the archaeological record extending into the Pliocene. By the middle Pleistocene hominids had settled in the Narmada Valley, a locality from which their fossil remains have been recovered. Late Pleistocene Homo sapien fossils have been removed and described in publications from several sites in Sri Lanka. However, the subcontinent has been slow in surrendering its potential contributions to the 
fuller story of hominid evolution, because systematic and long-term exploration has not characterized the protocol of foreign and South Asian paleoanthropologists (Petraglia 2001). Think of how Africa was neglected some half century ago and look what it has become today!

Biological anthropology, with its several subdisciplines, thrives today in Europe and the Americas, where the cultural-biological interface becomes more sharply defined. There is the awareness that the knowledge that the linguist, archaeologist, biological anthropologist, and sociocultural anthropologist command make it possible to form a consortium to create the core endeavor of the broad community of scholars who study the past (Szathmary 2000). In "rethinking the archive" of history and anthropology in South Asia, Dr. Saloni Mathur notes that, "Any concern with contemporary transnational or cultural configurations in South Asia, or with the future of the postcolonial nation state, must be considered in relation to colonial history and the specific formations of modernity it generated" (2000:89). This is a valuable insight contributing to the advancement of paleoanthropology in the Indian subcontinent in the next millennium. But the key to future success lies with those South Asian prehistorians and their biological anthropology colleagues who are willing to establish an intellectual community that crosses those domestic political boundaries that have inhibited collaboration between institutions. In so doing, there is the prospect of bringing their nations into the modern arena of worldwide paleoanthropology where it could receive the respect it deserves. South Asia is the new frontier for our better understanding of human evolution, and the new millennium holds the promise of realization of this goal. But the dawn of the twenty-first century reveals a crisis for survival in its immediate future. Wonderful materials are available to the paleoanthropologist in this part of the world that bridges the landmasses of Africa and eastern Asia as well as subtending the vast expanse of Central Asia. Prospects for original research by young paleoanthropologists and their pioneering of new approaches to morphometric and statistical analyses of South Asia's earlier peoples may well surpass what has been accomplished in other parts of the world. These are the components of high adventure in science! An invitation to the skeletal biologist to join archaeologists at their table and to ensure the continuity of paleoanthropology in South Asia are issues that demand resolution if this part of Asia is to find its rightful place in the scholarly community of those who are devoted to learning about human origins, biological diversity, and humankind's place in the natural world.

\section{REFERENCES CITED}

Allchin, B.

1995 Early human cultures and environments in the northern Punjab, Pakistan: An overview of the Potwar Project and the British Archaeological Mission in Pakistan (1981-1991). Memoir of the Archaeological Surve'y of India 32:150-167.

BALTAR, M.

2001 Scientists spar over claims of earliest human ancestor. Science 291:1460-1461.

Begun, D. R., C. V. WArd, and M. D. ROSE

1997 Function, Plologeny and Fossils: Miocene Hominoid Evolution and Adaptation. New York: Plenum Press.

Bhasin, M. K., H. Walter, and H. Danker-Hople

1994 People of India: An Investigation of Biological Variability in Ecological, Ethmo-economic and Linguistic Groups. Delhi: Kamra-Raj Enterprises. 
Bhattacharya, D. K.

2000 Anthropology in prehistoric archaeology: The Indian scene. Journal of Human Ecology 11(1) : 23-31.

Bioisi, T., AND L. J. Zimmerman, EDS.

1997 Indians and Anthropologist: Vine Deloria Jr. and the Critique of Anthropology. Tucson: University of Arizona Press.

BOAS, F.

1940 Race, Langunge and Culture. New York: Macmillan.

Cann, R. K.

1987 In search of Eve. The Sciences, September/October: 30-37.

Chaudhury, P.

1993 The Aryans: A Modern Myth. New Delhi: Eastern Publishers.

Corbey, R., and W. Roebroeks, eds.

2001 Studying Human Origins: Disciplinary History and Epistomology. Amsterdam: Amsterdam University Press.

DART, R. A.

1925 Australopithecus africanus: The man-ape of South Africa. Nature 115:195-199, 875.

DENNELL, R. W.

1998 Grasslands, tool-making and the hominid colonization of southern Asia: A reconsideration, in: Early Human Behavior in Global Context: The Rise and Diversity of the Lower Palacolithic Record: 280-303, ed. M. D. Petraglia and R. Korisettar. London and New York: Routledge.

2001 From Sangiran to Olduvai, 1937-1960: The quest for "centres" of human origins in Asia and Africa, in Studying Human Origins: Disciplinary History and Epistomology: 45-66, ed. R. Corvey and W. Roebroeks. Amsterdam: University of Amsterdam.

Deraniyagala, S. U.

1992 The Prehistory of Sri Lanka: 2 vols. Colombo: Archaeological Survey, Department of Archaeology.

DEWAR, E.

2002 Bones: Discovering the First Americans. New York: Carol and Graf.

DIXON, R. B.

1923 The Racial History of Man. New York: Charles Scribner's Sons.

GuнA, B. S.

1935 The racial affinities of the peoples of India, in Census of India 1931. Simla: Govermment of India Press.

Hemphill, B. E., J. R. Lukacs, and K.A.R. Kennedy

1991 Biological adaptations and affinities of Bronze Age Harappans, in Harappan Excavations 1986-1990: A Multidisciplinary Approach to Third Millennimm Urbanism: 137-182, ed. R. H. Meadow. Madison, WI: Prehistory Press.

Jarrige, J. F., ANd M. Lecinevaliter

1979 Excavations at Mehrgarh, Baluchistan: Their significance in the prehistorical context of the Indo-Pakistani borderlands, in South Asian Archacology 1977: 463-535, ed. M. Taddei. Naples: Istituto Univertsitano Orientale.

JONES, W.

1786 On the Hindus: The third anniversary discourse delivered 2 February 1786. Asiatick Researcles $1: 415-443$.

Kalb, J. E.

20()() Adventures in the Bone Trade: The Recent Discovery of Human Ancestors in Ethiopia's Afar Depression. New York: Copernicus Books.

KeITH, A.

1929) The Antiquity of Man. 2nd ed. London: Williams and Norgate.

KIENNEIDY, K.A.R.

1975 The Plysical Anthropology' of the Megalith-Builders of South India and Sri Lanka. Canberra: Australian National University Press.

1976 Human Varation in Space and Time. 1)ubuque: William C. Brown. 
1995 Have Aryans been identified in the prehistoric skeletal record from South Asia? Biological anthropology and the concepts of ancient races, in The Indo-Aryans of Ancicut South Asia: Langunge, Material Culture and Ethnicity: 32-66, ed. G. Erdosy. Berlin: Walter de Gruyter.

2000 God-Apes and Fossil Men: Palcoanthropology of South Asia. Ann Arbor: University of Michigan Press.

Kennedy, K.A.R., S. U. Deraniyagala, W. J. Roertgen, J. Chiment, and T. Disotell

1987 Upper Pleistocene fossil hominids from Sri Lanka. American Journal of Physical Anthropology' $72: 441-461$.

Kennedy, K.A.R., and R. L. CiOChON

1999 A canine tooth from the Siwaliks: First recorded discovery of a fossil ape? Human Evolution $14(3): 231-253$.

Kennedy, K.A.R., A. Sonakia, J. Chiment, and K. K. Verma

1991 Is the Namada hominid an Indian Homo erectus? American Journal of Physical Anthropology $86: 475-496$.

KEnNEDY, K.A.R., AND J. L. ZAHORSKY

1997 Trends in prehistoric archaeology and biological anthropology: New evidence from Pleistocene deposits at Fa Hien Cave, Sri Lanka, in Sonth Asian Archacology 1995: 839853, ed. B. Allchin. New Delhi: Oxford-IBH.

Kumar, S. S., I. Nasidze, S. R. Walimbe, and M. Stoneking

2000 Brief communication: Discouraging prospects for ancient DNA from India. American Journal of Pliysical Anthropology 113:129-133.

LEAKEY, L.S.B.

1959 A new fossil skull from Olduvai (Zinjanthropus boisei). Nature 184:491-493.

LEWIS, G. D.

1934 Preliminary note on new man-like apes from India. American Journal of Science $27: 161-181$.

LOVELl, N. C.

1997 Anaemia in the ancient Indus Valley. International Journal of Osteoarchacology 7:115-123.

LUKACS, J. R.

1984 Dental anthropology of South Asian populations: A review, in The People of South Asia: Biological Anthropology of India, Pakistan and Nepal: 133-157, ed. J. R. Lukacs. New York: Plenum Press.

Lukacs, J. R., And S. R. Walimbe

1998 Physiological stress in prehistoric India: New data on localized hypoplasia of primary canines linked to climate and subsistence change. Journal of Archacological Science $25: 571-585$.

Mathur, S.

2000 History and anthropology in South Asia: Rethinking the archive. Annual Revicu of Authropology 29:89-106.

MEADOW, R. H., ED.

1991 Harappa Excavations 1986-1990: A Multidisciplinary Approach to Third Milleminm Urbanism. Madison, WI: Prehistory Press.

Metzger, B. M., and M. 1). CoOgan, eds.

1993 The Oxford Companion to the Bible: 46-54. Oxford: Oxford University Press.

Misra, V. N., S. N. Rajaguru, G. L. Badam, R. K. Ranjoo, and R. Korisettar

1990 Further research in the prehistory and Quaternary geology of the Narmada Valley, in Adaptation and Other Essays: 53-58, ed. N. C. Ghosh and S. Chakrabarti. Santiniketan: Research Publications, Visva-Bharati.

Montagu, A.

1942 Man's Most Dangerous Myth: The Fallacy of Race. New York: Columbia University Press.

1951 Statement on Race. New York: Schuman.

1964 The Concept of Race, ed. A. Montagu. New York: Free Press.

Petraglia, M. D.

1998 The Lower Palaeolithic of India and its bearing on the Asian record, in Early Human Behaviour in Global Context: The Rise and Diversity' of the Louner Palacolithic Record: 343-390, ed. M. D. Petraglia and R. Korisettar. London: Routledge. 
2001 The Lower Palaeolithic of India and its behavioral significance, in Human Roots: Africa and Asia in the Middle Pleistocenc: 217-233, ed. L. Barham and K. Robson-Brown. Bristol: Western Academic and Specialist Press.

Pilbeam, D. R.

1997 Research on Miocene hominoids and hominid evolution, in Function, Plytogeny and Fossils: Miocenc Hominoid Evolution and Adaptation: 13-28, ed. D. R. Begun, C. V. Ward, and D. Rose. New York: Plenum Press.

Pilbeam, D. R., G. E. Meyer, C. Badgley, M. D. Rose, M.H.L. Pickford, A. K. Behrensmeyer, AND S. M. SHAH

1977 New hominoid primates from the Siwaliks of Pakistan and their bearing on hominoid evolution. Nature 270:689-695.

Pilbeam, D. R., M. D. Rose, J. C., Barry, and S. M. Ibrahim Shah

1990 New Sivapithecus humerus from Pakistan and the relationship of Sinapithecus and Pongo. Nature 348:237-239.

Pope, G. G.

1994 An historical and scientific perspective on paleoanthropological research in the Far East, in One Hundred Years of Pithecanthropus: The Homo erectus Problem: 23-32, ed. J. L. Franzen. Frankfurt-am-Main: Forschungsinstitut.

1996 Asian geochronology, paleobehavior and modem Asian origins. American Journal of Ply si- $^{-}$ cal Anthropology $22: 188$.

1997 Paleoanthropological research traditions in the Far East, in Conceptual Issues in Modern Origins Research: 269-282, ed. G. A. Clark and C. M. Willermat. New York: Aldine-De Gruyter.

Possehl, G. L.

1999 The Indus Age: The Beginning. New Delhi: Oxford-IBH.

Possehl, G. L., and M. H. Raval

1989 Harappan Civilization and Rojdi. New Delhi: Oxford-IBH.

REDDY, V. RAMi, ED.

1985 Dental Anthropology: Application and Method. New Delhi: Inter-Alia Publications.

RISLEY, H.

1908 The People of India. Calcutta: Thacker, Spink.

Sarich, V. M., and J. E. Cronin

1976 Molecular systematics of the primates, in Molecular Anthropology: 141-170, ed. M. Goodman and R. E. Tashian. New York: Plenum Press.

SARKAR, S. S.

1972 Ancient Races of the Deccan. New Delhi: Manoharlal.

Simons, E. L., AND D. R. Pilbeam

1965 Preliminary revision of the Dryopithecinae (Pongidae, Anthropoidea). Folia Primatologica $3(2-3): 81-152$.

SCHWIDETZKY, I.

1983 Short history of Indian-German relations in physical anthropology. Anthropologischer Anzeiger $41(2): 85-92$.

SKLENAF, K.

1983 Archacology in Central Europe: The First 500 Years. New York: St. Martin's Press.

Sмiтн, G. E.

1930) Human History. London: Jonathan Cape.

SONAKIA, A.

1984 The skull-cap of early man and associated mammalian fauna from Narmada valley alluvium, Hoshangabad area, Madhya Pradesh, India. Records of the Geological Survey of India $113: 159-172$.

SPENCER, F., ED.

1997 History of Physical Anthropology: An Encyelopedia. 2 vols. New York: Garland Press.

Stacul, G.

1987 Prehistoric and Protohistoric Sunat, Pakistan (c. 3000-1400 B.C.). Report and Memoirs of the Istituto Italiano par if Medio ed Estremo Oriente 2(). Rome: ISMEO. 
Stringer, G. B., And C. Gamble

1993 In Searle of the Neanderthals. London: Thames and Hudson.

SZATHMARY, E.J.E.

2000 A comment on the series: A view of the science: Physical anthropology at the millennium. American Journal of Plysical Anthropology 114:1-3.

TATTERSAll, I.

1997 Out of Africa again ... and again. Scientific American 276(4):46-53.

THOMAS, D. H.

2000 Skull Wars: Kennewick Man, Archaeology and the Battle for Native American Identity. New York: Basic Books.

UNESCO

1950 Statement on the Nature of Race and Race Differences by Physical Anthropologists and Geneticists: Revicu' of the 1950 Statement. New York: UNESCO Publications.

Walimbe, S. R., And S. S. Kulkami

1993 Biological Adaptation of Human Dentition: An Odontonnctric Study on Living and Archaeological Populations in India. Pune: Deccan College Publications.

Walimbe, S. R., And A. TAvaras

1992 A bio-cultural study of man in India. Man and Environnent 17:81-91.

Weiner, J. S., K. P. Oakley, and W. LeGros Clark

1953 The Solution of the Piltdonn Problem. Bulletin of the British Museum (Natural History), Geology Series 2(3).

WHEELER, R.E.M.

1968 The Indus Civilization. The Cambridge History of India. Supplementary Volume. 3rd ed. Cambridge: Cambridge University Press.

WHite, T. D.

2001 Review of Adventures in the Bone Trade: The Race to Discover Human Ancestors in Ethiopia's Afar Depression, by J. Kalb. Nature 410:517-518.

Willis, D.

1989 The Hominid Gang: Behind the Scenes in the Search for Human Origins. New York: Viking Press.

Wilson, E. O., And W. K. Brown

1953 The subspecies concept and its taxonomic applications. Systentatic Zoology $2: 97-111$.

WolpoFf, M. H.

1999 Palcoanthropology. 2nd ed. New York: McGraw-Hill.

Wolpoff, M. H., and R. CASPARI

1996 Why aren't Neanderthals modern humans? in The Lourer and Middle Paleolithic, Colloquium X: The Origin of Modern Man: Colloquia of the XIII International Congress of Prehistoric and Protohistoric Sciences: 133-156, ed. O. Bari-Hosef, L. L. Cavalli-Sforza, R. J. March, and M. Piperno. Forli: ABACO Edizioni.

\section{ABSTRACT}

Emerging from the philological-historical approaches of the eighteenth-century Orientalists, the scientific study of the hominid fossil record and prehistory of South Asia (India, Pakistan, Sri Lanka, and their borderlands) has a history of over two centuries. Today Western and South Asian scholars offer new answers to old questions about the origin and antiquity of the earliest hominids in the subcontinent, the beginnings of the Indus civilization, archaeological and skeletal interpretations about the reputed Indo-European-speaking Aryans of the Vedic tradition, biological affinities of ancient and modern populations, and palaeodemographic profiles of health and disease status, traumatic and developmental modifications, and population sizes and densities of earlier peoples in this part of Asia. At the beginning of the third millennium we respond to these issues in ways that modify or repudiate earlier theories and interpretations of archaeological and palaeontological data, e.g., 
a present-day recognition that hominids were present in the northwestern sector of the subcontinent during the geological period of the Pliocene-Pleistocene transition, the establishment of the roots of the Indus civilization in cultures established by 7000 B.C. and long before the period of the third millennium B.C. settlement and cultural diffusion, the fall of the Aryan migration myth and its racial and caste implications, and a reevaluation of population genetic affinities using DNA and more powerful statistical types of analysis of the skeletal record. This paper summarizes these and other recent advances in South Asian palaeoanthropology by noting transitions in scientific perspectives and present-day issues of research, and discusses prospects for the development of palacoanthropology in South Asia at the dawn of the new millennium in the light of specific crises that will be encountered by its future practitioners. Keywords: Palaeoanthropology, South Asia, research orientations. 